\title{
Making the Postwar Avant-garde More German
}

\author{
Marcus ZAGORSKI \\ Comenius University Bratislava \\ Gondova 2, Sk-81499 Bratislava, Slovakia \\ E-mail: marcus.zagorski@uniba.sk
}

(Received: April 2015; accepted: June 2015)

\begin{abstract}
At the heart of Carl Dahlhaus's historiographic interests, according to James Hepokoski, was an "effort to keep the Austro-German canon from Beethoven to Schoenberg free from aggressively sociopolitical interpretations." But Dahlhaus did not stop at Schoenberg: he also wrote about postwar music, and one might therefore wonder whether his "Austro-German canon" of autonomous music extended past 1945. In his essays on this period, Dahlhaus claimed that the postwar musical avant-garde was defined by the concept of the experiment, a concept that was, he believed, "nothing less than the fundamental aesthetic paradigm of serial and post-serial music." $\mathrm{He}$ maintained this view from the 1960s through the 1980s, and thereby placed the concept of the experiment at the center of his historiography of postwar music. My paper shows that the concept of the experiment, as defined by Dahlhaus, has a uniquely German pedigree, one that is not at odds with his wider historiographic interests. By making the concept of the experiment central to his account of postwar music, Dahlhaus was thereby able to extend his historiography beyond the canon that ran from Beethoven to Schoenberg and include also later composers. In so doing, he lent the supposedly "international" postwar avant-garde a character that seems specifically German.
\end{abstract}

Keywords: postwar music, aesthetics, historiography, Carl Dahlhaus

National music traditions were often promoted in totalitarian states after 1945 as better alternatives to the techniques of the Western avant-garde. This can be seen in music history texts and in the critical reception of contemporary music, where non-avant-garde traditions were made to seem superior because of their rootedness in a national heritage. But if nationalism was used to make the musical traditions promoted by totalitarian regimes seem more essential or more important 
than the Western avant-garde, then it seems worth asking: what about the Western avant-garde itself? Can we find associated with it the use of national - if not overtly nationalist - elements? And are there traces of these in music history writing and in the critical reception of contemporary music in the West?

In an attempt to answer these questions, I will consider perhaps the most prominent and prolific writer engaged with postwar music in the West during the period: Carl Dahlhaus. Dahlhaus's education and professional life were almost perfectly synchronous with the Cold War: he completed his Ph.D. dissertation in 1953, obtained his first academic post in 1962, and worked as a Professor in West Berlin from 1967 to $1989 .{ }^{1}$ During much of his creative life, and alongside his copious work on other historical periods, Dahlhaus was involved with contemporary music as few other musicologists were: he wrote numerous essays and participated in many conferences, festivals, and publications on the topic. But despite his dedication to the new music of his time, he is better known for his work on other periods, and his study of $19^{\text {th }}$-century music has received the most critical attention, especially in the English-speaking world.

One well-known example of this critical attention is James Hepokoski's article "The Dahlhaus Project and Its Extra-musicological Sources."2 According to Hepokoski, "the Dahlhaus Project was centrally concerned with $19^{\text {th }}$-century German music - more explicitly, with a connotation-saturated repertory that had been pivotal in establishing a German national identity." 3 And, further, "at the heart of the Dahlhaus Project was an effort to keep the Austro-Germanic canon from Beethoven to Schoenberg free from aggressively sociopolitical connotations." In other words, Dahlhaus not only favored particular $19^{\text {th }}$-century German (and Austrian) composers, he also espoused a methodology in which artistic content was primary and social context was secondary (or even non-existent): that is, he favored aesthetic autonomy.

Hepokoski's notion of a Dahlhaus "Project" - that is, of an unchanging methodology used in all of his work - should be challenged, for it can be argued that Dahlhaus was too critically aware to construct a closed system. ${ }^{5}$ Consider, for example, one of Hepokoski's main conclusions about Dahlhaus: "he seems most centrally concerned with constructing the [singular] 'History' of the Germanic institution of autonomous music." ${ }^{\prime 6}$ And compare this to a sentence written by Dahlhaus himself:

1. These dates are given in, among many other sources, Stephen Hinton, "Carl Dahlhaus: Biographie und Methode," in Carl Dahlhaus und die Musikwissenschaft: Werk, Wirkung, Aktualität, eds Hermann Danuser, Peter Gülke and Norbert Miller (Schliengen: Argus, 2011), 37-43. Translations are my own unless noted otherwise.

2. James Hepokoski, "The Dahlhaus Project and its Extra-musicological sources," $19^{\text {th }}$-Century Music 14/3 (Spring 1991), 221-246.

3. Ibid., 225 .

4. Ibid., 222.

5. For more on this point, see Marcus Zagorski, "Carl Dahlhaus and the Aesthetics of the Experiment," Acta Musicologica 87/2 (2015), 249-264.

6. Hepokoski, “The Dahlhaus Project," 235-236. 
... history taken in the extremely questionable singular has, to put it crudely, come to be seen as a myth. As an authority presiding over the activities of the individual it has lost the hold on people's minds which was established for it in the $19^{\text {th }}$ century by Hegel and Marx. ${ }^{7}$

Such sentences call into question Hepokoski's claims. Furthermore, Dahlhaus's writings taken as a whole reveal a dynamic essence to his thinking, and his later writings specifically challenged his earlier premises - a fact that makes the notion of a Dahlhaus "Project" implausible. ${ }^{8}$ But Hepokoski does show that aesthetic autonomy was a primary category for Dahlhaus - at least for his discussion of $19^{\text {th }}$-century music; ${ }^{9}$ and he provides a very insightful study of the reasons why Dahlhaus chose this category, reasons that go beyond the fact that the concept of autonomy suited the repertory. Specifically, Hepokoski argues that Dahlhaus was reacting against the rise of Marxist sociological theory in German universities at the time, and that he aligned himself with the older idea of autonomy and its "culturally conservative" proponents as a defensive measure. ${ }^{10}$ Among those purportedly "conservative" proponents were Gadamer, Jauss, Adorno, and the heritage of German idealistic philosophy and historiography upon which they built.

But if this is characteristic of Dahlhaus's treatment of the "Austro-Germanic canon from Beethoven to Schoenberg," what about after Schoenberg? What about the postwar period? For that is, after all, the focus of the present article. As noted above, Dahlhaus was engaged with postwar music to an extent few others could match. What did he say about this music? One good place to look for an answer to this question is in the concept that Dahlhaus called "nothing less than the fundamental aesthetic paradigm of serial and post-serial music." This "fundamental aesthetic paradigm" was, he said, the concept of the experiment. ${ }^{11}$ And he claimed that "the postwar musical avant-garde was defined by the concept of the experiment." 12 On the surface, there might seem to be nothing nationalistic or particularly German in the statements quoted here. The notion of experimentation has a praiseworthy scientism that sounds neutral and international. And scientific metaphors are relevant to the time: even Richard Taruskin, certainly no apostle

7. Carl Dahlhaus, “A Rejection of Material Thinking?," in idem, Schoenberg and the New Music, trans. Derrick Puffett and Alfred Clayton (Cambridge: Cambridge University Press, 1987), 274-287, here 277.

8. More information about the changes in Dahlhaus's writing over the course of his career can be found in Hinton, "Biographie und Methode," 41.

9. Hepokoski, "The Dahlhaus Project," 245.

10. Ibid., 225.

11. "Der Begriff des Experiments, als Gegenbegriff zu dem des Werkes, sei nichts Geringeres als das fundamentale ästhetische Paradigma der seriellen und postseriellen Musik gewesen." Carl Dahlhaus, "Die Krise des Experiments," in Komponieren Heute, ed. Ekkehard Jost (Mainz: Schott, 1983) (= Veröffentlichungen des Instituts für Neue Musik und Musikerziehung 23), 80-94, here 84. Emphasis added.

12. "[Die] Kategorie des Experiments... [ist eine] Kategorie, von der das musikalische Denken der Avantgarde nach dem Zweiten Weltkrieg über weite Strecken bestimmt worden ist.” Dahlhaus, “Die Krise,” 84. Emphasis added. 
of Dahlhaus, begins his own account of postwar music with the claim that "in the immediate postwar period, science and technology enjoyed an unprecedented prestige," though it was a prestige quickly moderated by anxiety and unease. ${ }^{13}$ Additionally, in pointing to the concept of the experiment, Dahlhaus was pointing to one of the key terms of the period: the article on the term "Experiment" in the Handwörterbuch der musikalischen Terminologie, for example, documents its wide usage in the 1950s and 1960s. ${ }^{14}$

But a closer look at Dahlhaus's description of the concept of the experiment reveals features that are specifically German. To see this, we need to examine the several components that he said are part of the concept. These include: first, an idea of musical material that was indebted to Adorno, and the corresponding philosophy of history behind that idea; second, a related, so-called "problem-history" of composition that unfolded in a similar way to the history of science; and third, the idea of a "work-in-progress," which challenged an older work concept inherited from the nineteenth century. ${ }^{15}$ In what follows, these three components and their ties to German intellectual history will be examined in turn. ${ }^{16}$

The first component, and perhaps the most essential, is a philosophy of history modeled on the development of new musical materials. In this conception of history, new compositional techniques were seen to emerge from older ones not because of the subjective preferences of individuals, but because of the supposedly objective dictate of historical progress, the belief in which enabled composers to justify new techniques as required rather than chosen. Free atonality was said, for example, to lead logically to the 12-tone method; the 12-tone method for ordering pitch was seen then to expand to the ordering of duration, loudness, and timbre in total serialism; and finally, the application of serial methods to these so-called "parameters" expanded further in post-serial techniques such as sound-composition. ${ }^{17}$ This succession of techniques suggests that the concept of the experiment applied specifically to European music rather than the music of so-called American experimental composers. ${ }^{18}$ And indeed, the writings of many postwar Euro-

13. Richard Taruskin, The Oxford History of Western Music, vol. V: The Late Twentieth Century (Oxford: Oxford University Press, 2005), 2.

14. Christoph von Blumröder, s.v. "Experiment, experimentelle Musik," in Handwörterbuch der musikalischen Terminologie, Sonderband I: Terminologie der Musik im 20. Jahrhundert, ed. Hans Heinrich Eggebrecht (Stuttgart: Franz Steiner, 1995).

15. Dahlhaus, "Die Krise," 82-85.

16. For a more detailed study of Dahlhaus's aesthetics of postwar music, see Zagorski, "Carl Dahlhaus."

17. These historical stages are mentioned in Dahlhaus, "Die Krise," 83.

18. Interestingly, it could be argued that the so-called "American experimental tradition" has nationalistic traits: by creating the myth of an American experimental tradition, American composers attempted to create a national tradition that expressed the legitimacy of their own music as independent from the European tradition. Ironically, the notion of an American experimental tradition seems to have been invented by the German composer Wolfgang Rebner for a lecture at the Darmstadt Summer Courses. For more on Rebner's lecture, see Amy C. Beal, "Negotiating Cultural Allies: American Music in Darmstadt, 1946-1956," Journal of the American Musicological Society 53/1 (2000), 105-139. Other American composers, not usually included among the so-called experimental group, also compared composition to experimentation; see, for example, Milton 
pean composers, all of whom were either German or active in West Germany, give voice to this philosophy of history. It can be found verbatim in essays by Dieter Schnebel, Gottfried Michael Koenig, György Ligeti, and Luigi Nono; and there are similar versions of it in the writings of Karlheinz Stockhausen, Pierre Boulez, and Helmut Lachenmann. It stemmed, in large part, from Adorno, who admitted without shame that his own music philosophy was dependent upon the concept of an "objective Spirit" inspired by Hegel's philosophy of history and developed in the book Dialektik der Aufklärung. ${ }^{19}$

This philosophy of history was said by Dahlhaus to represent a "problem-history" of composition, for each new compositional approach was thought to solve problems found in the previous approach, and each new approach introduced new problems that required yet newer approaches for solution. This "problem-history" is the second component I noted as being essential to Dahlhaus's concept of the experiment. ${ }^{20}$ Such a "problem-history" was modeled on the history of science, he argued, and, specifically, the theory of "normal science" outlined in The Structure of Scientific Revolutions, a book by the American scholar Thomas Kuhn. ${ }^{21}$ But Dahlhaus's "problem-history" also has German roots that he does not mention. Perhaps the clearest parallels can be found in an essay by Stockhausen titled "Erfindung und Entdeckung" [or "Invention and Discovery"], published in 1961. In this essay, Stockhausen described his compositions of the 1950s as a series of problems begetting solutions, which he illustrated with nearly 20 pages of examples from his scores: each new composition was said by Stockhausen to solve a problem contained in the preceding composition..$^{22}$ Another source for Dahlhaus's idea of a "problem-history," was Hans-Georg Gadamer's book Wahrheit und Methode (Truth and method), which outlined a historical model based upon a "logic of question and answer," something Dahlhaus knew intimately. ${ }^{23}$

Babbitt's essay “Twelve-Tone Rhythmic Structure and the Electronic Medium," Perspectives of New Music 1/1 (Fall 1962), 109-140.

19. For a detailed study of this philosophy of history, including an explanation of its use in theoretical writings by the composers mentioned here, see Marcus Zagorski, "Material and History in the Aesthetics of 'serielle Musik'," Journal of the Royal Musical Association 134/2 (2009), 271-317.

20. Descriptions of the "problem-history" can be found in Dahlhaus, "Die Krise," 83 and 91; see also: Carl Dahlhaus, "Neue Musik und Wissenschaft," in Wissenschaftliche und nichtwissenschaftliche Rationalität: Ein deutsch-französisches Kolloquium, eds Kurt Hübner - Jules Vuillemin (Stuttgart: Frommann-Holzboog, 1983), 107-118, specifically 109; Carl Dahlhaus, "Vom Mißbrauch der Wissenschaft," in idem, Schönberg und Andere: Gesammelte Aufsätze zur Neuen Musik (Mainz: Schott, 1978), 388-398, specifically 393-394; and idem, "A Rejection of Material Thinking," 280-281.

21. Thomas Kuhn, The Structure of Scientific Revolutions (Chicago: University of Chicago Press, ${ }^{3} 1996$ ). For Dahlhaus's comparison, see for example Dahlhaus, "Die Krise,” 83.

22. Karlheinz Stockhausen, "Erfindung und Entdeckung: Ein Beitrag zur Form-Genese," in idem, Texte, Bd. 1, ed. Dieter Schnebel (Köln: DuMont, 1963), 222-258, see especially 230-250. It is probably no coincidence that among the many references to Stockhausen in the Dahlhaus Gesammelte Schriften, Dahlhaus names this Stockhausen essay most frequently.

23. See Hans Georg Gadamer, Wahrheit und Methode. Grundzüge einer philosophischen Hermeneutik (Tübingen: Mohr Siebeck, ${ }^{4} 1975$ ). A detailed comparison between Dahlhaus and Gadamer is given in Hepokoski's "Dahlhaus Project." 
The idea of a "problem-history" in composition went hand-in-hand with the idea of a "work-in-progress," which is the third component of Dahlhaus's concept of the experiment. He understood the work-in-progress as a counter-concept to the $19^{\text {th }}$-century ideal of a closed musical work and a consequence of the problem-history: because new pieces could only be understood as solutions to problems posed by earlier pieces, no individual piece in the problem-history of postwar music could be seen to be a closed whole. This challenge to the $19^{\text {th }}$-century ideal of a closed work can be found in essays by Stockhausen and Ligeti, both of whom argued for the need to overturn the older aesthetic of a closed, perfected work. ${ }^{24}$ But if their idea challenged the ideal of a closed work, it did not question the ideal of aesthetic autonomy. In fact, it could be argued that the work-in-progress places greater emphasis on aesthetic autonomy, for it suggests that individual pieces can only be understood correctly as technical solutions to technical problems: the history of technique is all that matters for the work-in-progress, and social praxis is excluded entirely.

In fact, all three components of the concept of the experiment-the material aesthetic and corresponding philosophy of history, the idea of a problem-history, and the idea of a work-in-progress-could be interpreted as having allowed Dahlhaus to keep his focus on aesthetic autonomy. They could even be seen as an example of what Hepokoski called Dahlhaus's greatest historiographic concern: that is, writing history in a way that makes technique primary and social context secondary. ${ }^{25}$ In these respects, Dahlhaus's work on the postwar avant-garde resembles his work on $19^{\text {th }}$-century music, where autonomy is not only central, but is said to be the most appropriate critical perspective from which to view the repertory. ${ }^{26}$ Given the diversity of music in both periods, this is obviously a limited, and limiting, perspective.

Dahlhaus's perspective on postwar music could be criticized as being limited in certain respects. But is he also vulnerable to the charge that he favored German composers (or those who were active in West Germany) and German intellectual history? Dahlhaus was no nationalist: he did not openly assert the primacy of a German tradition, nor could he do so given the history of Germany in the decades before 1950. But it can be argued that his writings favor German intellectual history and art. On the other hand, one must consider the context: this was the

24. See Karlheinz Stockhausen, "Zur Situation des Metiers (Klangkomposition)," in Texte, Bd. 1, 45-61; and György Ligeti, "Pierre Boulez. Entscheidung und Automatik in der Structure 1a," die Reihe 4 (1958), $38-63$.

25. Hepokoski refers specifically to Dahlhaus's desire, expressed in Foundations of Music History, to write an art history "that is a history of art," by which he means a history of primarily technique; see Carl Dahlhaus, Foundations of Music History, trans. J. B. Robinson (Cambridge: Cambridge University Press, 1983), 129.

26. Dahlhaus, Foundations, 32-33. One could argue that the division between work and social praxis that Dahlhaus thought justified his focus on autonomy for $19^{\text {th }}$-century music was even more pronounced for much music after 1945. 
tradition he knew best, and his focus on it might be interpreted as an effort to rehabilitate a culture that had been abused and damaged by the Third Reich. ${ }^{27}$ In light of this point, it would be fruitful to ask what differences pertain between the terms "national" and "nationalist" and how we should understand individuals" work in relation to these differences.

Given Dahlhaus's focus on autonomy and German intellectual history, we might also ask what in his work is useful and worth preserving, and what, conversely, is less useful today. I have explored this question in detail elsewhere, ${ }^{28}$ and argued that Dahlhaus's methodological awareness, his self-critique, and his drive to find a kind of criticism that is arguably appropriate to his topic are worth keeping. They are worth keeping, for example, as correctives to certain trends in so-called "new musicology." For in "new musicology" one sometimes finds the same tendency to preformed conclusions that Dahlhaus objected to in the "vulgar Marxism" that dominated the universities of his time (and encouraged him to privilege the concept of autonomy). ${ }^{29}$ In both cases, some scholars seem to know what they will find before they even look and regardless of what they are looking at. Or, at least, it seems they do not always subject their conclusions to as much critical reflection as did Dahlhaus.

With respect to what is less useful today, one might say that self-critique is never less useful, even in periods when it is unfashionable. But one thing that might bring Dahlhaus's work more compellingly into the present would be a willingness to admit into his method that which he separated from the exclusive realm of aesthetic autonomy ${ }^{30}$ Were he alive today, now that Marxist criticism has fewer blind adherents in academia, one would expect that he might be more willing to ease his grip on autonomy. For similar reasons, he might need to ease his grip on the concept of the experiment. Music after 1945, and especially after 1960, is most remarkable for its pluralism, for its blurring of the distinction between high and low culture, and for the use of non-Western and non-autonomous traditions. The concept of the experiment cannot adequately explain such trends; but that may be precisely why Dahlhaus wrote of the "crisis of the experiment," with the clear intent of stressing that what seemed valid in the 1950s, in the West, was no longer valid in the 1980 s.

In other words, as the political landscape of Europe, and the Cold War itself, changed, so did the cultural landscape. And this point returns us to the opening questions about nationalism and the Western avant-garde, questions that are essentially about the relation between musical practice and cultural context. Just as

27. For more on Dahlhaus's life during the National Socialist period in Germany, see Hinton, "Biographie und Methode," 42.

28. See Zagorski, "Carl Dahlhaus."

29. For more on Dahlhaus's objection to "vulgar Marxism" see Hepokoski's "The Dahlhaus Project."

30. Stephen Hinton argues that Dahlhaus began to do this in his later writings; see Hinton, "Biographie und Methode." 
nationalism in music in the totalitarian state was used as a tool for expressing the primacy of other musical traditions over Western avant-garde music, so too were aesthetic autonomy, the concept of the experiment, and the (German) intellectual history behind these ideas used to assert the primacy of Western avant-garde music. The Western avant-garde may have seen itself as an international movement, but its local features become more prominent with the distance afforded by the passage of time. 